\title{
Comparison of PWM Techniques and Inverter Performance
}

\author{
Raja Ram Kumar ${ }^{1}$, Sunil Kumar², Alok Yadav ${ }^{3}$ \\ ${ }^{1,2,3}$ (Electrical Engineering, IIT (BHU) Varanasi, India)
}

\begin{abstract}
Due to large application of induction motors in industries, it has become prudent to work on its speed control. As the inverter provides better sinusoidal voltage or current, speed control of machines becomes more fine. It is possible only if inverter gets better gate pulses. Hence for testing of quality of inverter output voltage or current, \%THD and switching frequency are two important parameter. It also contain the output voltage or current at $3 \mathrm{k} \mathrm{Hz}$ switching frequency.
\end{abstract}

Keywords - Different methods of PWM Techniques, SIMULINK Model of Different Techniques, Output characteristics of inverter, \%THD of Output of Voltage or current Vs switching frequency.

\section{INTRODUCTION}

Alternating current (AC) power can be achieved from direct current (DC) power at desired output current or voltage and frequency through inversion [1]. Voltage-fed and current-fed are commonly used terms in inverter circuits. In voltage source inverter (VSI) DC input voltage is normally constant and it is also does not dependent on the load current which is drawn from it. The load voltage is decided by inverter and waveform of current is determined by the load. Power supply network (or) a rotating alternator through a rectifier (or) a battery, fuel cell, photo voltage array (or) Magneto Hydro Dynamic (MHD) generator provides DC input power to inverter. Inverter is of two types, voltage Source Inverters (VSI), and Current Source Inverters (CSI). In voltage source inverter DC source has small or negligible impedance that is it has stiff DC voltage source at its terminals. Low internal impedance provides the approximately constant voltage even after varying the load [2], [3]. Hence it is suitable to single motor and multi-motor drives. Short circuit at its terminal causes current to rise very fast, due to its low internal impedance. Current control does not regulate the fault current and hence should be cleared by fast acting fused links [4]. Normally machines do not perform smoothly due to large amount of \%THD, which causes noise, vibration and heating in machines. Enough amount of research has already been done in this area suggesting different techniques for speed control of machines. The purpose of this paper is to give a detailed comparison of different techniques for control of induction machine. Through this paper, depending on the simulation result, a detailed comparison of the different techniques for control of machines has been done. This comparison is done on the basis of \% THD at different frequencies for voltage and current.

\subsection{Modulation Techniques}

The fundamental idea of the PWM technique is to compare a high frequency wave or signal known as the carrier signal (a triangular signal with frequency $\mathrm{f}_{\mathrm{s}}$ ) to a signal of low frequency known as the referencemodulating signal ( with frequency $\mathrm{f}_{\mathrm{m}}$ ). The frequency of the reference-modulating signal $\mathrm{f}_{\mathrm{m}}$ is set the desired output frequency [4] [5]. In Sinusoidal Pulse width modulation technique for getting the pulses, it is required to compare sine wave with triangular wave [6] and in similar way Trapezoidal modulation is a technique to advance the control ability by using computation of PWM patterns. The output frequency of the converter is decided with the frequency of the modulating wave [7].Space vector PWM (SVPWM) is a digital modulating technique because its control strategies are implemented in digital systems. The purpose of this technique is to produce PWM load line voltages which are in average equal to given (or reference) load line voltages. Inverter with PWM is three stage separate push pull driver, which produces phase waveform independently. SVPWM inverter is used to offer 15\% increase in the utilization of dc-link voltage and output which have low harmonic distortions in comparison to conventional sinusoidal PWM inverter. In SVPWM inverter is considered as single unit; specifically, the inverter can be driven to eight unique stages [8], [9].

\section{Simulink model with different pulses}

It is our motive to analyses the performance of inverter by giving above pulses to the 3-phase inverter. For this, it is required to develop three Simulink models for respective PWM techniques for the purpose of comparison of their output line voltages or current quality. Quality means what $\%$ of harmonic of its fundamental is present in line voltage or current which is provided to the stator to the motor. Hence $\%$ THD (total harmonics distortion) determines which output voltage is more close to sine wave. 


\subsection{Simulink model with SPWM technique}

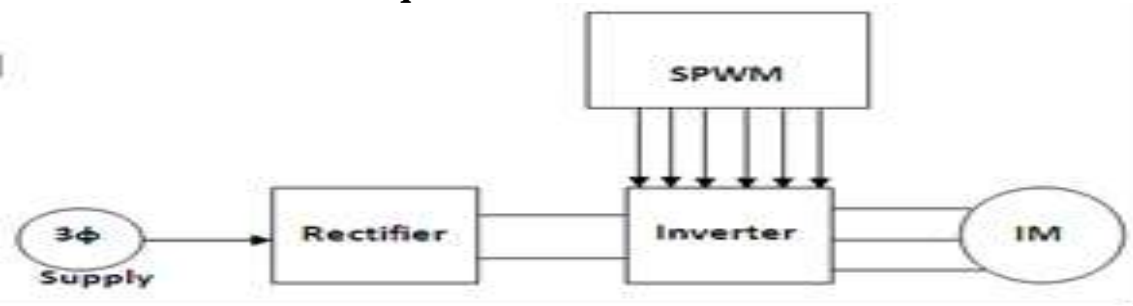

Fig. 1 Block diagram for SPWM

The Simulink results are shown at Switching frequency $\left(\mathrm{f}_{\mathrm{s}}\right)=3 \mathrm{kHz}$, DC voltage $\left(\mathrm{V}_{\mathrm{dc}}\right)=352 \mathrm{~V}$, Frequency of reference wave $(\mathrm{f})=50 \mathrm{~Hz}$, Modulation index $(\mathrm{M})=1$

Simulink Results

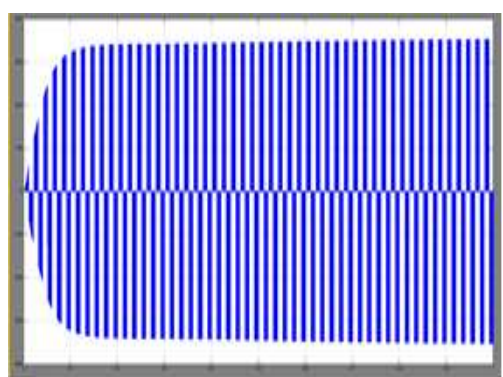

Fig. 2 Output of line voltage of SPWM technique

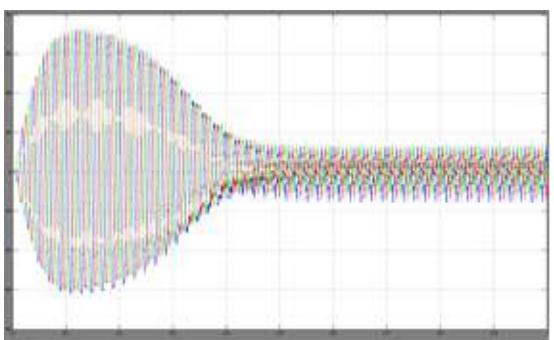

Fig. 4 3-phase stator current of SPWM technique

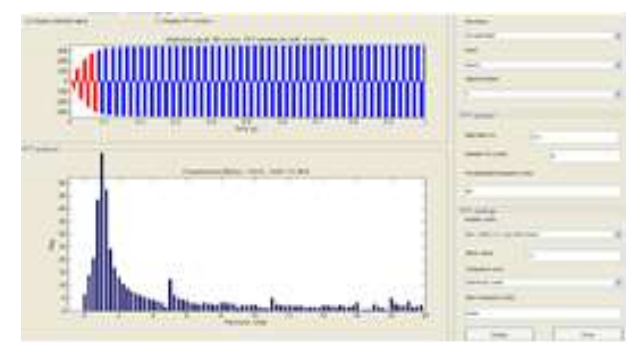

Fig.3 FFT analysis with \%THD Output of line Voltage of SPWM technique

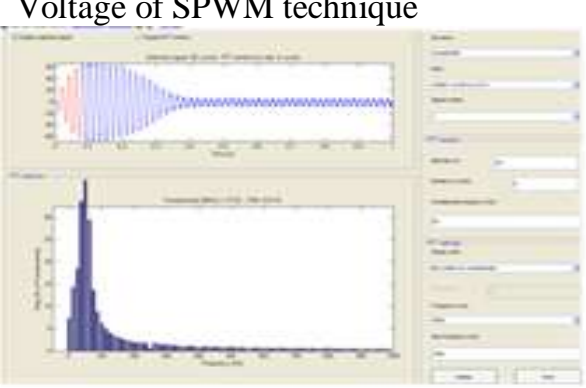

Fig.5 FFT analyses with \%THD in stator current of SPWM technique

\subsection{Simulink model with trapezoidal PWM technique}

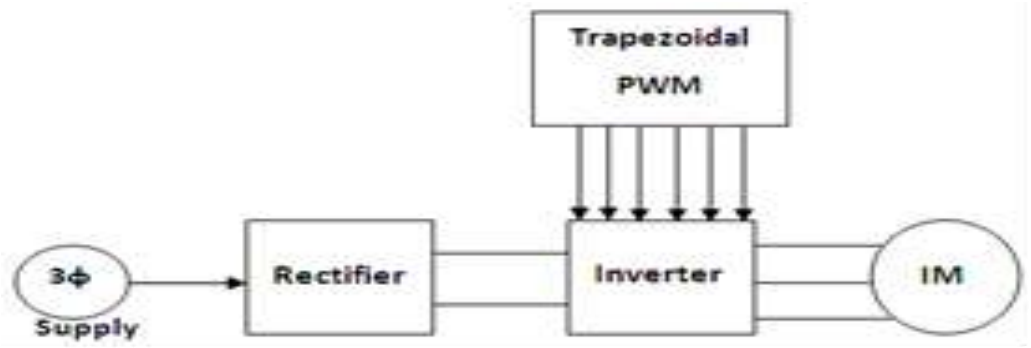

Fig. 6 Block Diagram for Trapezoidal PWM

The Simulink results are shown at Switching frequency $\left(\mathrm{f}_{\mathrm{s}}\right)=3 \mathrm{kHz}, \mathrm{DC}$ voltage $\left(\mathrm{V}_{\mathrm{dc}}\right)=352 \mathrm{~V}$, , Frequency of reference wave $(\mathrm{f})=50 \mathrm{~Hz}$, Modulation index $(\mathrm{M})=1$ 
Simulink Result

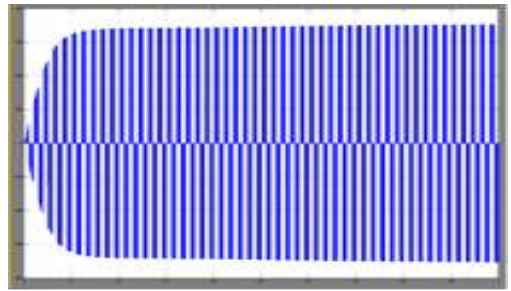

Fig. 7 Output of line voltage of trapezoidal PWM technique

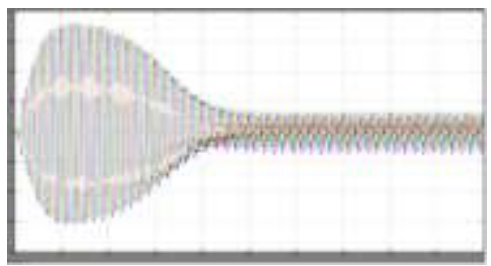

Fig. 9 3-phase stator current of Trapezoidal PWM technique

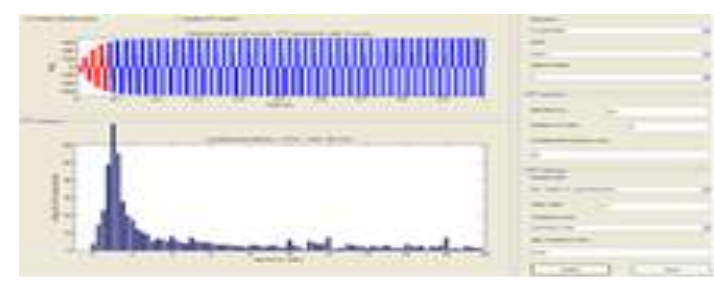

Fig. 8 FFT analysis with \%THD Output of line voltage of trapezoidal PWM

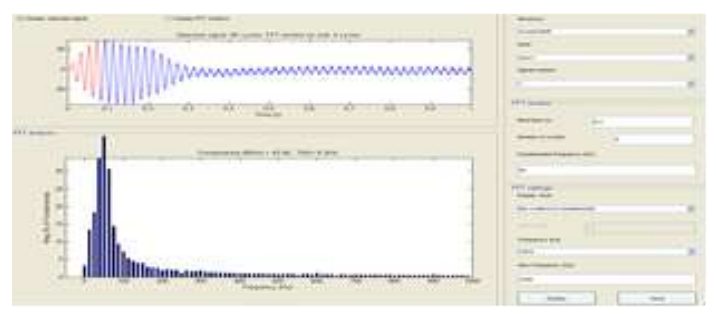

Fig. $10 \mathrm{FFT}$ analyses with \%THD in stator current of trapezoidal PWM techniaue

\subsection{Simulink model with SVPWM technique}

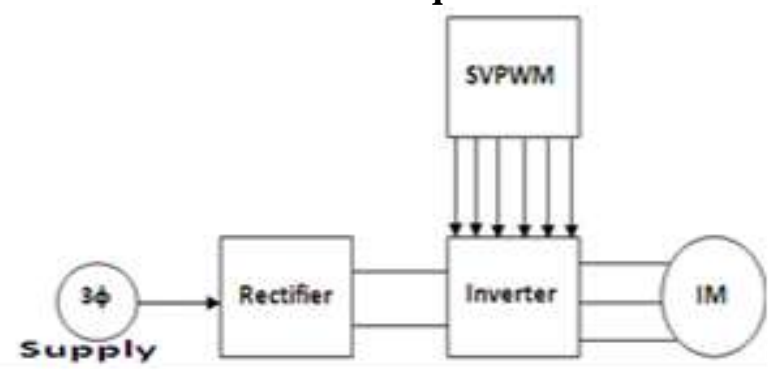

Fig. 11 Block Diagram for SVPWM

The Simulink results are shown at Switching frequency $\left(\mathrm{f}_{\mathrm{s}}\right)=3 \mathrm{kHz}$, DC voltage $\left(\mathrm{V}_{\mathrm{dc}}\right)=352 \mathrm{~V}$, Frequency of reference wave $(\mathrm{f})=50 \mathrm{~Hz}$, Modulation index $(\mathrm{M})=1$

Simulink Result

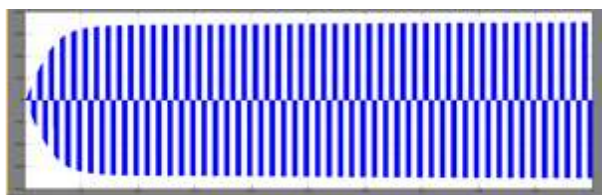

Fig. 12 Output of line voltage of SVPWM Technique

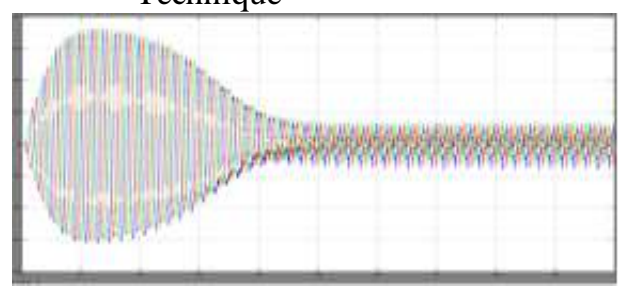

Fig. 14 3-phase stator current of SVPWM Technique

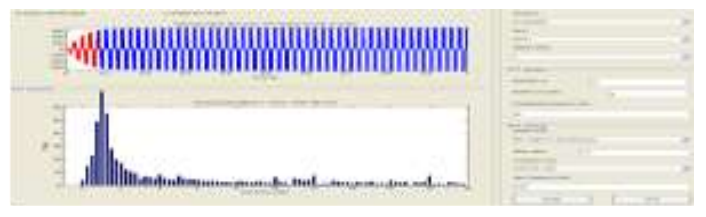

Fig.13 FFT analysis with \%THD Output of line voltage of SVPWM technique

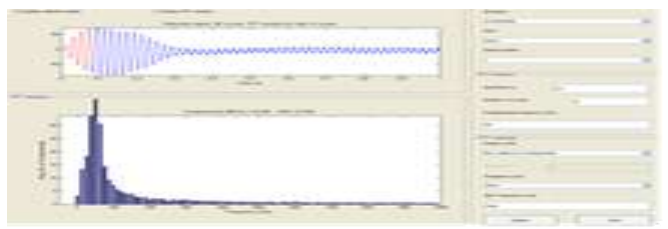

Fig. 15 FFT analysis with \%THD in stator current of SVPWM technique

Comparison of total harmonic distortion (\%THD) of different technique of PWM 
Table I Comparison Result of \% THD for output Line voltage of inverter

\begin{tabular}{|l|l|l|l|l|}
\hline Switching frequency & $\mathbf{1 5 0}$ & $\mathbf{1 0 0 0}$ & $\mathbf{2 0 0 0}$ & $\mathbf{3 0 0 0}$ \\
\hline SPWM $(\%$ THD $)$ & $\mathbf{5 3 . 8 8}$ & $\mathbf{5 5 . 7 0}$ & $\mathbf{6 2 . 5 7}$ & $\mathbf{7 2 . 3 5}$ \\
\hline Trapezoidal $(\%$ THD) & $\mathbf{5 2 . 7 0}$ & $\mathbf{5 4 . 4 9}$ & $\mathbf{6 2 . 3 5}$ & $\mathbf{5 9 . 3 1}$ \\
\hline SVPWM(\%THD) & $\mathbf{5 2 . 7 0}$ & $\mathbf{5 3 . 5 7}$ & $\mathbf{5 4 . 3 5}$ & $\mathbf{5 9 . 3 1}$ \\
\hline
\end{tabular}

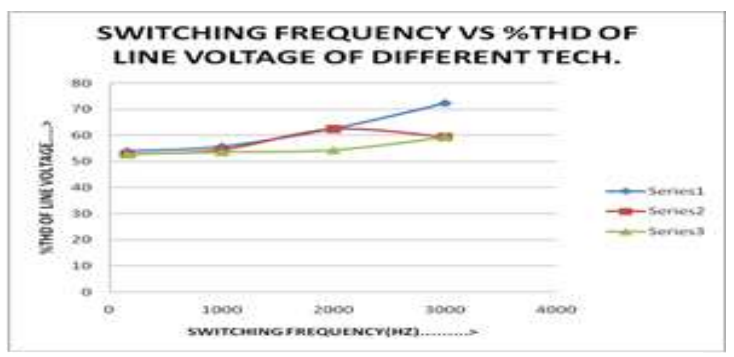

Fig. 16 switching frequency Vs \%THD of line voltage of different technique

Table II Comparison Result of \% THD for stator Current of induction motor

\begin{tabular}{|l|c|c|c|c|}
\hline Switching frequency & 150 & 1000 & 2000 & 3000 \\
\hline SPWM(\%THD) & 13.58 & 11.06 & 8.43 & 8.01 \\
\hline Trapezoidal(\%THD) & 11.06 & 10.86 & 8.01 & 9.25 \\
\hline SVPWM(\%THD) & 11.06 & 8.43 & 8.01 & 9.25 \\
\hline
\end{tabular}

Table III Comparison Result of \% THD for output rotor Current of induction motor

\begin{tabular}{|l|c|c|c|c|}
\hline Switching frequency & 150 & 1000 & 2000 & 3000 \\
\hline SPWM(\%THD) & 13.86 & 8.34 & 5.60 & 5.32 \\
\hline Trapezoidal(\%THD) & 8.34 & 7.32 & 5.32 & 5.35 \\
\hline SVPWM(\%THD) & 8.34 & 5.60 & 5.32 & 5.35 \\
\hline
\end{tabular}

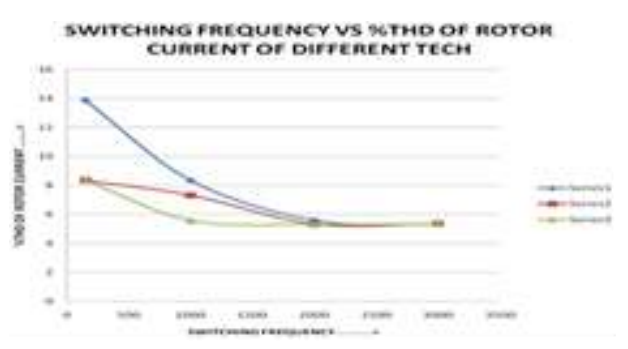

Fig. 18 switching frequency vs. \% THD of Rotor Current of different technique

\section{Conclusion}

From the above table-I shows that as the switching frequency of carrier wave increases \% THD in line output voltage increases which reduces the output voltage. Table-II show that as the switching frequency of carrier wave increases, the \% THD in stator current decreases which tell that as switching frequency increases stator current will be more closer to sinusoidal with decrease current that makes flux sinusoidal in air gap of motor, that reflect of reduced \% THD of rotor current .In table-III , as the switching frequency of carrier wave
Table IV Rating of 3-phase induction motor used for Simulink model [10]

\begin{tabular}{|l|l|}
\hline $\begin{array}{l}\text { INDUCTION } \\
\text { MOTOR(SQUIRRELCAGE) }\end{array}$ & RATING \\
\hline PHASE & 3 \\
\hline VOLTAGE & 220 \\
\hline AMP. & 14.03 \\
\hline FREQUENCY & 60 \\
\hline SPEED & 1750 \\
\hline POWER & $3 \mathrm{hp}$ \\
\hline $\begin{array}{l}\text { CONNECTION(STATOR AND } \\
\text { ROTOR) }\end{array}$ & $\begin{array}{l}\text { Wye to internal neutral } \\
\text { point }\end{array}$ \\
\hline
\end{tabular}


increases, the \%THD in rotor current decreases, this reduces pulsating torque which also reduces the acoustic noise of motor. As move from table II-IV that also shows the performance of the motor with the pulse SVPWM which is applied to inverter is better than TRAPEZOIDAL and SPWM.

\section{Acknowledgment}

Throughout the tiresome period of research, a number of people stood by us and were of great help. Here, we would like to record our sincere gratitude and appreciation to all those who provided help, support, and encouragement, enabling us to complete our research paper. It gives us immense pleasure to express our deep sense of gratitude and heartfelt thanks to Assistant professor Dr.S.K.Sing, Associate professor Dr. R.K.Saket and Professor Dr. R.K.Srivastava for their unfailing support, practical guidance, and fatherly attitude right from the beginning until this work came to life.

Our sincere thanks also go to Mr.Lokesh wasney, Mr. Amardeep keshri, Mr. Harish Balgah, Ravi Kumar and our all friends of the Department of Electrical engineering, IIT-BHU.

\section{Books:-}

\section{References}

[1] S.Hasan Saeed, Automatic control systems sixth revised edition 2008

[2] Dr. P.S.Bimbhra "power electronics, Fourth edition, 2009

\section{Papers:-}

[3] Mahesh A. Patel, Ankit Patel, Dhaval R.Vyas and Ketul Patel "Use of PWM Techniques for power Quality" International Journal of Recent Trends in Engineering, Vol. 1, No. 4, May 2009"

[4] Zhang Wei, Luo Jian Jun "Speed and Rotor Flux Estimation of Induction Motors Based on Extended Kalman Filter" Zhejiang Wanli University Ningbo, China IEEE Conference, Page(s): 157 - 160, Cited by 1, Publication, Year: 2010

[5] R.Arulmozhiyal1, K.Baskaran2, R.Manikandan “An Intelligent Speed Controller for Indirect Vector Controlled Induction Motor Drive"978-1-4244-5967-4/10/\$26.00 @2010 IEEE

[6] Literature Number: BPRA073, Field Orientated Control of 3-Phase AC-Motors, Texas Instruments Europe, February 1998

[7] V. NAGA BHASKAR , "Comparison of Modulation Techniques for Multilevel Inverter fed Permanent Magnet Synchronous Motor" International Journal of Engineering Science and Technology Vol. 2(10), 2010, 5206-5214

[8] Ing. Pavel Gajdůšek, "Programmable Laboratory Invertor and Space Vector PWM Hardware Implementation and Application Setup for Pc Based Control of Induction Motor" Msm Project No. 0021630516

[9] Muhammad H .Rashid "Power Electronics circuits, Devices and Applications "Third Edition, Sixth Impression,2009

[10] www.mathwork.com 